\title{
INTERACTION OF HEAVY METALS IN THE SOIL-PLANT SYSTEM OF URBAN GARDENS IN ATHENS, GREECE
}

\author{
Kazantzoglou A. ${ }^{1}$, Argyraki A. ${ }^{1}$, Papageorgiou S. ${ }^{1}$ and Fadel D. ${ }^{2}$
}

${ }^{1}$ National \& Kapodistrian University of Athens, Faculty of Geology \& Geoenvironment, Panepistimiopolis Zographou, 15784, Athens, Greece,nancykaza1993@hotmail.com, argyraki@geol.uoa.gr,papagstamatiou@hotmail.com

${ }^{2}$ Lebanese University, Faculty of Agricultural Engineering, Damour, Lebanon, dr.danifadel@gmail.com

\begin{abstract}
Preliminary data on the interaction between soil and edible plants with respect to heavy metal concentrations in Athens, Greece are presented. Concentration ranges of $\mathrm{Zn}, \mathrm{Cu}, \mathrm{Ni}, \mathrm{Cr}, \mathrm{Co}, \mathrm{Mn}, \mathrm{Fe}, \mathrm{Ba}, \mathrm{Pb}$ and $\mathrm{Cd}$ in soils and vegetables collected from urban allotments in Athens are determined and assessed taking into account the pseudototal (extracted by aqua regia) and mobilizable $(0.43 \mathrm{M}$ acetic acid extractable) concentrations of the elements in the rhizosphere soil of the collected plants as well as the total concentrations in plant tissue. Average elemental concentrations in urban allotments are lower than the ones previously reported for Athens urban soil. No detectable concentrations of the non-essential heavy metals $P b$ and $C d$ were measured in the studied plants while concentrations of micronutrient elements in plants are within normal ranges. The collected data indicate that previous land use is an important factor controlling heavy metal content in soil and that there is a complex mechanism controlling micronutrient uptake by plants.

Keywords: Biogeochemistry, soil contamination, micronutrient elements, urban agriculture.

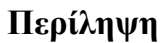

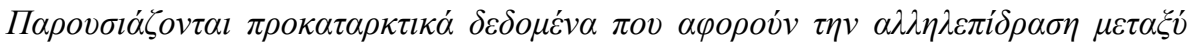

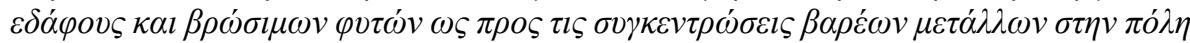

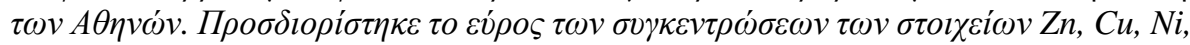

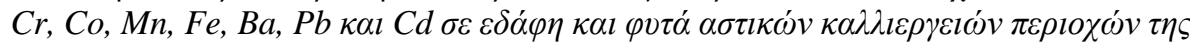

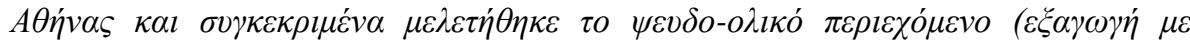

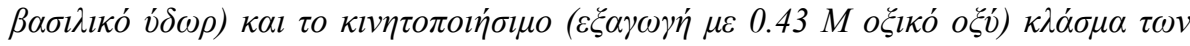

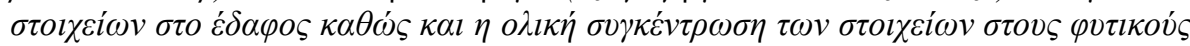

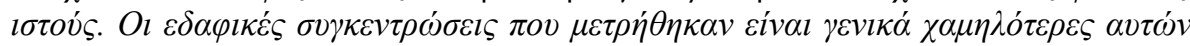

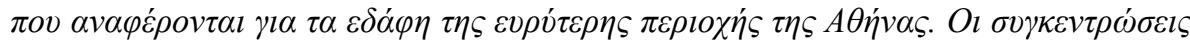

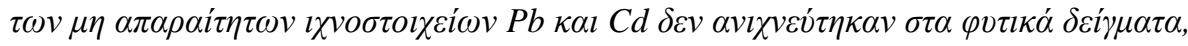

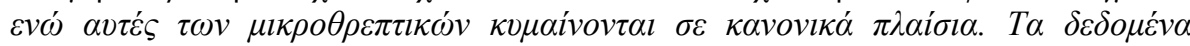

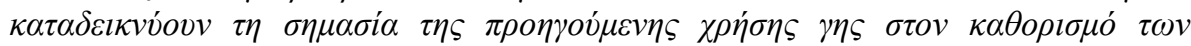

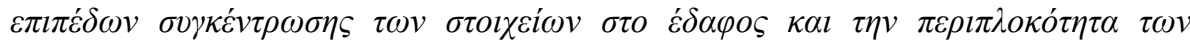

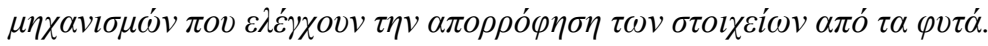

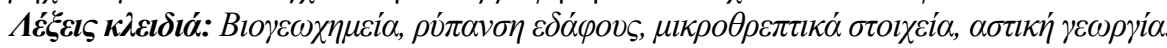




\section{Introduction}

In recent years, the application of urban agriculture has risen dramatically and is at a climax. Not only have municipalities taken an active role on that matter, but also much domestic cultivation is apparent in urban areas. At the same time the urban ecosystem is being weakened by excessive heavy metal loadings in the environment, resulting from the continuous production and use of industrial commodities. Furthermore, a growing body of scientific evidence shows that heavy metal contamination in the urban soil might be related to the natural geochemical background (e.g. Manta et al., 2002; Rodrigues et al., 2009; Argyraki and Kelepertzis, 2014). All of the above might lead to soil pollution. Through plant uptake and the food chain, heavy metals may be passed on to humans resulting in possible adverse health effects. The concentration of heavy metals in plant tissue largely depends on the soil-plant transfer. It is generally known that there are variations in the rates between different plant species but also between the same plant species from different areas (Kabata-Pendias and Pendias, 1992). It has also been observed that previous land uses of the cultivated areas have a significant contribution to the levels of heavy metal contamination of soil and plants (Tahmasbian et al., 2013).

The aim of the present study is to present preliminary data on the interaction between soil and edible plants with respect to heavy metal concentrations in Athens, Greece. The specific objectives were: a) to determine the concentration range of $\mathrm{Zn}, \mathrm{Cu}, \mathrm{Ni}, \mathrm{Cr}, \mathrm{Co}, \mathrm{Mn}, \mathrm{Fe}, \mathrm{Ba}, \mathrm{Pb}$ and $\mathrm{Cd}$ in vegetables collected from urban allotments in Athens, and b) to assess the pseudototal and mobilizable concentrations of the same elements in the rhizosphere soil of the collected plants.

\section{Materials and Methods}

\subsection{Field sampling and chemical analyses}

Twenty composite plant and 20 rhizosphere soil samples were collected from cultivated communal allotments in Athens, Greece organized by the municipalities of Agios Dimitrios, and Maroussi in the respective areas and by the NGO "The Center of Earth" in Tritsis Park, Ilion. Additional samples were collected from cultivated house gardens in Filothei, Neo Irakleio and Elliniko. All sampling took place during the spring of 2015.

In the laboratory, plants were thoroughly washed three times with deionized water and air dried at room temperature. The edible parts of the plants were separated before drying and kept for further analysis. All plant samples were ground in an agate mill and concentrations of heavy metals ( $\mathrm{Zn}$, $\mathrm{Cu}, \mathrm{Ni}, \mathrm{Cr}, \mathrm{Co}, \mathrm{Mn}, \mathrm{Fe}, \mathrm{Ba}, \mathrm{Pb}$ and $\mathrm{Cd}$ ) were measured by Inductively Coupled Plasma Optical Emission Spectroscopy (ICP-OES) in the University of Porthsmouth, UK following microwave digestion by $\mathrm{HNO}_{3} / \mathrm{H}_{2} \mathrm{O}_{2}, 6: 1 \mathrm{v} / \mathrm{v}$. Soil samples were oven dried at $40^{\circ} \mathrm{C}$ for 3 days, sieved using a $2 \mathrm{~mm}$ nylon sieve and ground using an automated agate mill. Pseudototal heavy metal concentrations in soil were measured by ICP-OES following digestion by a mixture of $\mathrm{HNO}_{3}, \mathrm{H}_{2} \mathrm{O}_{2}$ and $\mathrm{HCl}$ (USEPA, 2002). Acetic acid ( $0.43 \mathrm{M})$ extractable concentrations of heavy metals were also measured by the same analytical technique after mixing $1 \mathrm{~g}$ of the soil samples with $40 \mathrm{ml}$ acetic acid and shaking for $16 \mathrm{~h}$ at room temperature in an overhead shaker.

All utensils which were used during laboratory work, were thoroughly cleaned between the samples in order to avoid cross contamination. Analytical quality control procedures included the performance of duplicate analysis, the inclusion of blank solutions and certified reference materials of soils (NIST SRM 2709 and NIST SRM2711a for the total analysis and BCR-483 and BCR-484 for the acetic acid extraction) at random positions within the analytical batches. The results of the analytical control were found within acceptable limits for all analyses and all elements.

\subsection{Measurement of physicochemical parameters of soil}

The major physicochemical soil properties were measured including $\mathrm{pH}$, organic matter content and texture (sand, silt, clay). Soil $\mathrm{pH}$ was measured after mixing each $<2 \mathrm{~mm}$ soil sample with deionized 
water in a solid -to-liquid ratio of 1:2.5 (ISO, 1994). Organic matter content of the soil samples was estimated by the loss-on-ignition (LOI) method (US-EPA, 2002) by heating $1 \mathrm{~g}$ of each sample to $450^{\circ} \mathrm{C}$ for 4 hours in a furnace oven. Since the method determines the organic matter content in the soil, a conversion factor of 1.724 has been used to convert organic matter to organic carbon based on the assumption that organic matter contains $58 \%$ organic C (i.e., g organic matter/l $.724=\mathrm{g}$ organic $\mathrm{C}$ ). The grain size distribution in the sand, silt and clay fractions was determined using the Bouyoucos Hydrometer Method (Bouyoucos, 1962).

\section{Results and Discussion}

\subsection{Heavy metals in soil samples}

The measured pseudototal concentrations of heavy metals in soils samples are presented in Table 1. The summary statistics of elemental concentrations as well as the major physicochemical properties including $\mathrm{pH}$, total organic carbon (TOC) are presented in Table 2 . The alkaline soil $\mathrm{pH}$ values in this study, ranging from 8.0 to 9.0, are in agreement with data reported in earlier studies of Athens soil (Argyraki and Kelepertzis, 2014), reflecting the abundant presence of calcite in bedrock (Kelepertzis and Argyraki, 2015). The TOC average value of $3 \%$ is considered normal for urban agriculture soils and is slightly over the $2 \%$ TOC average reported by Kelepertzis and Argyraki (2015) for Athens soil. However, in contrast to other studies (Rodrigues et al., 2009) no significant correlations were detected between the key soil properties and the pseudototal concentrations of heavy metals.

Median values of the pseudototal elemental concentrations in soil are following the decreasing order $\mathrm{Fe}>\mathrm{Mn}>\mathrm{Ba}>\mathrm{Zn}>\mathrm{Ni}>\mathrm{Cr}>\mathrm{Co} \sim \mathrm{Pb} \sim \mathrm{Cu}>\mathrm{Cd}$. In comparison with median values in Athens soil reported by Kelepertzis and Argyraki (2015), all elements present significantly lower concentrations except $\mathrm{Co}$ and $\mathrm{Cd}$ that display comparatively elevated levels in the studied urban agriculture soil. Acetic acid extractability ratios expressed as \% percentages of the pseudototal concentrations are presented in Figure 1. The decreasing order of extractable concentrations is somehow similar to that of pseudototal concentrations except for Fe which has the lowest extractability ratio despite being the element with the highest pseudototal concentration. Similar acetic acid extractability ratios of $\mathrm{Zn}$ $(\sim 15 \%)$ and $\mathrm{Ni}(\sim 5 \%)$ have been reported by Kelepertzis and Argyraki (2015) however, relatively higher extractabilities of $\mathrm{Mn}$ and Co were measured in the present study. It is noted that the anthropogenic influence has been shown to be the dominant factor controlling $\mathrm{Pb}, \mathrm{Zn}, \mathrm{Cd}$ and $\mathrm{Cu}$ concentrations in Athens soil (Argyraki and Kelepertzis, 2014).

\subsection{Heavy metals in edible plant tissues}

The elemental concentrations in plant tissues are presented in Table 1. Plant tissue content of heavy metals is generally much lower than the respective content of rhizosphere soil (Table 1 and Figure 2). Concentrations of $\mathrm{Pb}$ and $\mathrm{Cd}$ were below detection limit in all plant samples. Normal concentrations of $\mathrm{Cu}$ in plants are in the order of $6 \mathrm{mg} / \mathrm{kg}$ for lettuce and $4 \mathrm{mg} / \mathrm{kg}$ for carrots and onions (Jaworowski, 1981). Relatively lower $\mathrm{Cu}$ content was measured in the present study for the respective vegetables. Barium is reported to be commonly present in plants, but it apparently is not an essential component of plant tissues. Barium concentration in the present study was within the normal ranges in plants from 1 to $198 \mathrm{mg} / \mathrm{kg}$ (Kabata-Pendias and Pendias, 1979). The rate of $\mathrm{Zn}$ absorption differs greatly among both plant species and growth media (Kabata-Pendias and Pendias, 2001).

The measured concentrations of $\mathrm{Zn}$ are similar to those mentioned in the bibliography for selected species, i.e. $44 \mathrm{mg} / \mathrm{kg} \mathrm{Zn}$ in lettuce, $24 \mathrm{mg} / \mathrm{kg}$ in carrots and $22 \mathrm{mg} / \mathrm{kg}$ in onion (Warren et al., 1970). Most soils contain significant amounts of Cr but its availability to plants is highly limited. Data from the present study totally agree with this fact. The Mn content shows a remarkable variation depending on plant species, stage of growth and different organs as well as for different ecosystems; the range of $\mathrm{Mn}$ in samples of the present study is $80 \mathrm{mg} / \mathrm{kg}$. It is known that when $\mathrm{Fe}$ is easily 
soluble, plants may take up a very large amount of Fe. Measured concentrations of Fe in lettuce, cabbage, carrots and onions are very close to those reported by Kabata-Pendias and Pendias (1979). The rates of Co are very low and the ability of plant species to absorb Co varies considerably (Kabata-Pendias and Pendias, 2001). An extreme outlying value has been observed for this element in sample KZ16 (beetroot). This value was not taken into account in statistical calculations.

Finally, the Ni content of plants growing on uncontaminated soils may vary considerably because it reflects both environmental and biological factors. However, the Ni concentrations in certain food products from different countries do not differ widely (Kabata-Pendias and Pendias, 2001). Generally, Ni levels in plants of the present study are very low. In general, the elements that are more easily absorbed by plants in the present study include $\mathrm{Fe}, \mathrm{Zn}, \mathrm{Mn}$ and $\mathrm{Ba}$ while the uptake of $\mathrm{Co}, \mathrm{Cu}, \mathrm{Ni}$ and $\mathrm{Cr}$ is very low. In terms of plant species, spinach and chicory- especially the Italian variety- seem to preferably concentrate $\mathrm{Zn}, \mathrm{Cu}$ and $\mathrm{Fe}$ in their leaves (Figure 2), although the small number of plant samples does not allow to draw any general conclusions.

The main sources of trace elements in plants are their growth media, for example, nutrient solutions or soils. One of the most important factors that determine the biological availability of trace element is its binding to soil constituents. In general, plants take up the species of trace elements that are dissolved in soil solution in either ionic or chelated and complex forms (Kabata-Pendias and Pendias, 2001). Furthermore, each plant species responds differently and according to its specific metabolic functions regarding the uptake of micronutrients. Following this, one can explain why there is no correlation between pseudototal elemental concentrations in soil and plant tissue (Figure 2). Also, when the rates of acetic acid extractable concentrations in soil samples are compared with the rates of concentrations in plant samples no significant correlation is noticeable for any of the studied elements. This observation indicates that the particular reagent is not effective for dissolving the chemical forms of elements that are up taken by plants. This in turn, might be related to the rather alkaline soil conditions prevailing in the study area as well as the speciation of the studied elements in soil samples.

\subsection{Comparison of heavy metal plant uptake between the studied communal urban allotments}

Since urban agriculture is an upcoming trend in modern cities it is of interest to compare the three communal allotments within the Athens urban net that were studied in this research in terms of land management and micronutrient concentrations in their produce. Based on a questionnaire that was distributed to the allotment managers it was found out that organic crop growing is practiced in all three of them without any application of chemical soil improvers, fertilizers and pesticides. Plants are irrigated with water originating from municipal boreholes. Previous land use varied from unused urban space in Maroussi, to horse stables in Parko Tritsi and parking area in Agios Dimitrios. In the later, the surface soil layer $(0-50 \mathrm{~cm})$ had been removed and new soil was brought in before starting the communal garden. All three allotments are used for communal agriculture for the past three years. 
Table 1 - Sample codes, plant species and their respective pseudototal concentrations of elements in soil (S) and plant tissue (P). Concentrations are expressed in mg/kg. Sampling sites are coded as E: Elliniko, AD: Agios Dimitrios, PT: Parko Tritsi, F: Filothei, M: Maroussi, NI: Neo Irakleio. bdl= below detection limit.

\begin{tabular}{|c|c|c|c|c|c|c|c|c|c|c|c|c|c|c|c|c|c|c|c|c|c|}
\hline 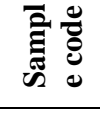 & $\begin{array}{l}\text { Scientific } \\
\text { name }\end{array}$ & $\begin{array}{l}\text { Common } \\
\text { name }\end{array}$ & $\stackrel{g}{\frac{\pi}{4}}$ & $\begin{array}{c}\mathbf{Z n} \\
\mathrm{S}\end{array}$ & $\begin{array}{c}\mathbf{Z n} \\
\mathbf{P}\end{array}$ & $\begin{array}{c}\mathrm{Cu} \\
\mathrm{S}\end{array}$ & $\begin{array}{c}\mathbf{C u} \\
\mathbf{P}\end{array}$ & $\begin{array}{l}\mathrm{Ni} \\
\mathrm{S}\end{array}$ & $\begin{array}{l}\mathbf{N i} \\
\mathbf{P}\end{array}$ & $\begin{array}{l}\mathrm{Cr} \\
\mathrm{S}\end{array}$ & $\begin{array}{c}\mathrm{Cr} \\
\mathbf{P}\end{array}$ & $\begin{array}{c}\text { Co } \\
\text { S }\end{array}$ & $\begin{array}{c}\text { Co } \\
\mathbf{P} \\
\end{array}$ & $\begin{array}{c}\text { Mn } \\
\text { S }\end{array}$ & $\begin{array}{c}\text { Mn } \\
\mathbf{P}\end{array}$ & $\begin{array}{c}\mathrm{Fe} \\
\mathrm{S}\end{array}$ & $\begin{array}{c}\mathbf{F e} \\
\mathbf{P}\end{array}$ & $\begin{array}{c}\mathbf{B a} \\
\mathbf{S}\end{array}$ & $\begin{array}{c}\mathbf{B a} \\
\mathbf{P}\end{array}$ & $\begin{array}{c}\mathbf{P b} \\
\mathrm{S}\end{array}$ & $\begin{array}{c}\mathrm{Cd} \\
\mathrm{S}\end{array}$ \\
\hline KZ37 & Allium сера & onion & $\mathrm{E}$ & 101 & 19 & 32 & 3 & 61 & 4.0 & 56 & 0.8 & 37 & 11 & 395 & 16 & 13038 & 78 & 138 & 11 & 31 & 2.2 \\
\hline KZ16 & Beta vulgaris & beetroot & $\mathrm{AD}$ & 79 & 39 & 26 & 7 & 56 & 23 & 40 & 9.8 & 37 & 2800 & 546 & 28 & 13870 & 186 & 185 & 79 & 28 & 2.6 \\
\hline KZ28 & Beta vulgaris & beetroot & PT & 99 & 43 & 28 & 12 & 70 & 2.6 & 65 & 0.7 & 33 & 6.0 & 292 & 29 & 8870 & 181 & 143 & 97 & 34 & 2.4 \\
\hline KZ20 & Beta vulgaris var sicla & mangel & $\mathrm{AD}$ & 74 & 46 & 18 & 7 & 61 & 2.8 & 46 & 1.5 & 44 & 2.6 & 506 & 49 & 15751 & 273 & 150 & 27 & 25 & 2.5 \\
\hline KZ25 & Brassica oleracea & cabbage & PT & 98 & 41 & 76 & bdl & 65 & 2.2 & 67 & 0.2 & 34 & 2.2 & 345 & 20 & 10539 & 64 & 181 & 12 & 52 & 2.2 \\
\hline KZ24 & Cichorium endivia & endive & PT & 66 & 41 & 31 & 9 & 75 & 2.7 & 77 & 1.0 & 35 & 4.8 & 328 & 57 & 9956 & 72 & 144 & 14 & 77 & 2.3 \\
\hline KZ5 & Cichorium indybus & chicory & $\mathrm{F}$ & 81 & 66 & 27 & 12 & 47 & 3.2 & 32 & 1.0 & 43 & 1.6 & 319 & 40 & 13057 & 166 & 149 & 19 & 31 & 2.4 \\
\hline KZ6 & Cichorium indybus & chicory & $\mathrm{F}$ & 77 & 58 & 24 & 11 & 39 & 4.2 & 29 & 1.2 & 43 & 2.4 & 320 & 55 & 12861 & 149 & 186 & 23 & 45 & 2.5 \\
\hline KZ22 & Cichorium indybus & chicory & PT & 66 & 81 & 38 & 5 & 66 & 3.2 & 69 & 0.5 & 34 & 3.4 & 334 & 59 & 10310 & 131 & 159 & 24 & 35 & 2.3 \\
\hline KZ15 & Cichorium indybus & italian chicory & $\mathrm{AD}$ & 78 & 92 & 28 & 7 & 53 & 4.0 & 39 & 2.7 & 44 & 8.6 & 523 & 84 & 14745 & 356 & 187 & 33 & 24 & 2.4 \\
\hline KZ18 & Cichorium indybus & italian chicory & $\mathrm{AD}$ & 72 & 116 & 18 & 10 & 54 & 3.8 & 47 & 1.3 & 37 & 5.8 & 464 & 63 & 12989 & 159 & 164 & 18 & 29 & 2.3 \\
\hline KZ23 & Dacus carota & carrot & PT & 61 & 30 & 35 & 3 & 63 & 2.6 & 66 & 1.4 & 34 & 1.2 & 323 & 4 & 9998 & 66 & 144 & 31 & 27 & 2.3 \\
\hline KZ33 & Dacus carota & carrot & $\mathrm{M}$ & 61 & 21 & 20 & bdl & 29 & 2.0 & 22 & 1.0 & 45 & 6.8 & 321 & 7 & 12332 & 92 & 101 & 19 & 17 & 2.3 \\
\hline KZ29 & Lactula sativa & iceberg & $\mathrm{M}$ & 109 & 40 & 54 & 5 & 78 & 2.6 & 79 & 1.1 & 43 & 6.4 & 385 & 39 & 11589 & 191 & 161 & 21 & 60 & 2.4 \\
\hline KZ12 & Lactula sativa & lettuce & NI & 96 & 43 & 43 & 3 & 49 & 3.0 & 41 & 1.3 & 44 & 24 & 270 & 14 & 12895 & 183 & 104 & 18 & 21 & 2.3 \\
\hline KZ27 & Lactula sativa & lettuce & PT & 64 & 38 & 39 & 5 & 98 & 2.6 & 80 & 0.7 & 35 & 4.0 & 352 & 28 & 10390 & 162 & 132 & 18 & 31 & 2.3 \\
\hline KZ26 & Petroselinum crispum & parsley & PT & 64 & 32 & 27 & 2 & 56 & 3.0 & 37 & 0.8 & 39 & 3.8 & 439 & 21 & 12341 & 84 & 142 & 137 & 17 & 2.4 \\
\hline KZ21 & Spinacia oleracea & spinach & $\mathrm{AD}$ & 62 & 124 & 19 & 13 & 51 & 3.4 & 40 & 1.9 & 37 & 5.4 & 448 & 42 & 13878 & 331 & 162 & 16 & 21 & 2.4 \\
\hline KZ17 & Vicia faba & beans & $\mathrm{AD}$ & 72 & 47 & 20 & 9 & 55 & 3.6 & 41 & 2.5 & 40 & 4.6 & 494 & 46 & 14064 & 336 & 189 & 21 & 22 & 2.4 \\
\hline KZ32 & Vicia faba & beans & $\mathrm{M}$ & 71 & 22 & 24 & 5 & 69 & 2.4 & 50 & 1.3 & 44 & 7.8 & 425 & 62 & 14381 & 213 & 119 & 18 & 21 & 2.3 \\
\hline
\end{tabular}


Table 2 - Summary statistics ( $n=20)$ of pseudototal heavy metal concentrations in soil (S) and plants (P), soil pH and soil OC. Concentrations are expressed in $\mathrm{mg} / \mathrm{kg}$.

\begin{tabular}{|c|c|c|c|c|}
\hline & Minimum & Maximum & Median & Std.Deviation \\
\hline $\mathrm{ZnS}$ & 61 & 109 & 78 & 15 \\
\hline $\mathrm{Zn} \mathrm{P}$ & 19 & 124 & 52 & 30 \\
\hline $\mathrm{Cu} \mathrm{S}$ & 18 & 76 & 31 & 14 \\
\hline $\mathrm{Cu} \mathrm{P}$ & 2 & 13 & 7 & 3 \\
\hline $\mathrm{NiS}$ & 29 & 98 & 60 & 15 \\
\hline $\mathrm{Ni} P$ & 2 & 23 & 4 & 4 \\
\hline $\mathrm{CrS}$ & 22 & 80 & 51 & 18 \\
\hline $\mathrm{Cr} \mathrm{P}$ & 0 & 10 & 2 & 2 \\
\hline Co S & 33 & 45 & 39 & 4 \\
\hline Co P & 1 & 24 & 6 & 5 \\
\hline Mn S & 270 & 546 & 391 & 83 \\
\hline Mn P & 4 & 84 & 38 & 21 \\
\hline $\mathrm{Fe} \mathrm{S}$ & 9000 & 15800 & 12410 & 1866 \\
\hline Fe P & 64 & 356 & 174 & 91 \\
\hline $\mathrm{BaS}$ & 101 & 189 & 152 & 26 \\
\hline $\mathrm{BaP}$ & 11 & 137 & 33 & 33 \\
\hline $\mathrm{Pb} \mathrm{S}$ & 17 & 77 & 32 & 15 \\
\hline $\mathrm{Cd} \mathrm{S}$ & 2.2 & 2.6 & 2.3 & 0.1 \\
\hline Soil pH & 7.83 & 8.82 & 8.43 & 0.23 \\
\hline Soil OC & 2 & 5 & 3 & 1 \\
\hline
\end{tabular}

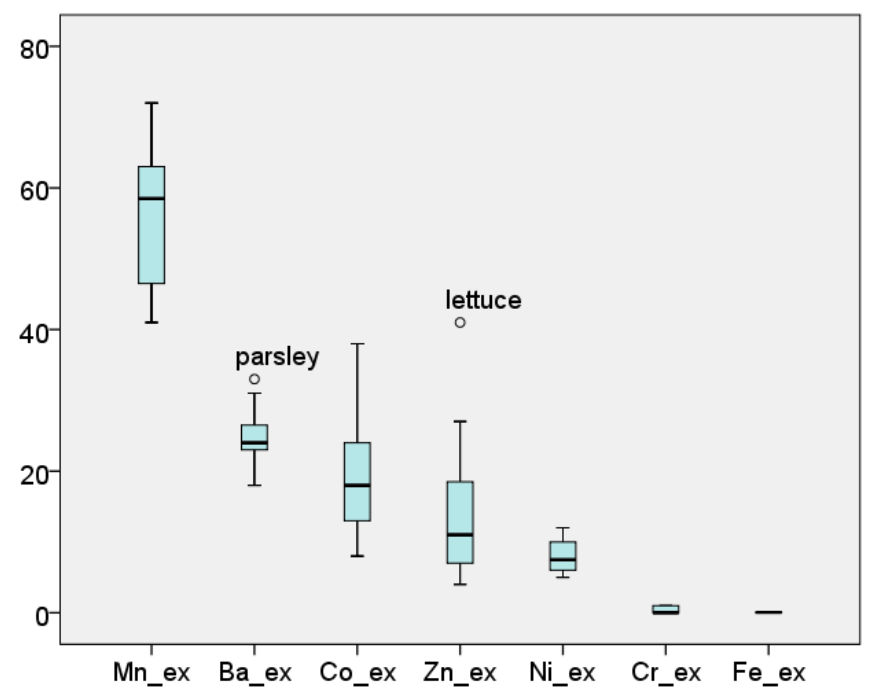

Figure 1 - Boxplot comparison of acetic acid extractability ratios of heavy metal concentrations and variation in the studied soil samples. The elements are ordered according to decreasing median value (horizontal lines). The y axis scale shows \% extractability. Two outlying values are denoted by circles (one for parsley and one for lettuce). 

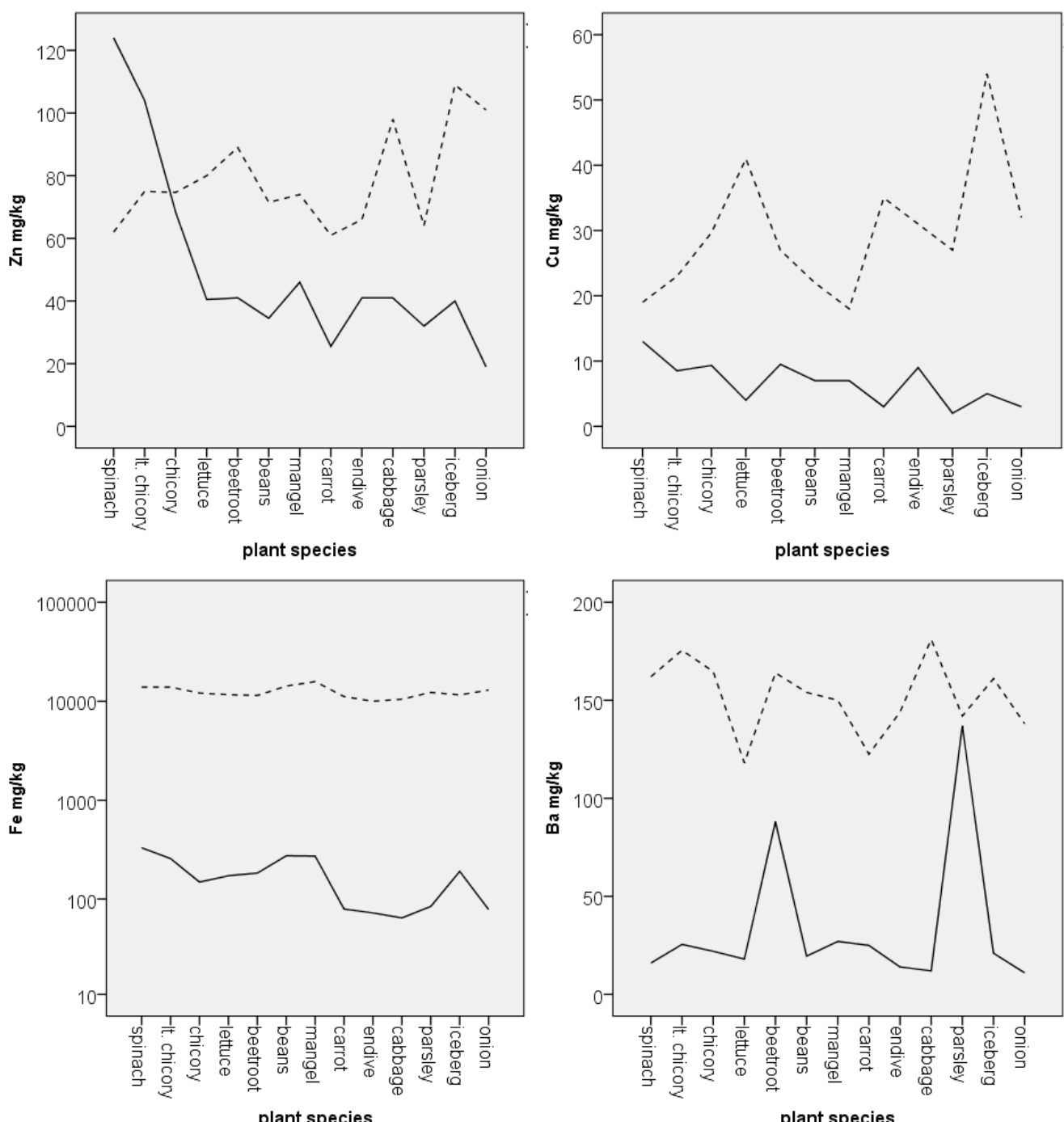

Figure 2 - Comparison the various plant species collected in this study with respect to selected elements' concentrations in plant tissues (continuous lines) and their respective rhizosphere soil (dotted lines).

Elemental concentrations in soil and plants of the three studied areas are compared using side by side box-plots in Figure 3. Although no specific trend is observed, a noticeable greater variance exists for most of the elements in Maroussi soil compared to the other two areas, while the opposite holds for plant elemental content. Differences of elemental concentrations in soil might be related to the previous land use of the study areas. Also, variation of the median values in plants exceeds the respective variation in soil medians between the three areas. The vegetable produce in Agios Dimitrios contains the highest concentrations of $\mathrm{Zn}, \mathrm{Cu}, \mathrm{Cr}$ and $\mathrm{Fe}$. However, taking into account that different plant species were sampled in each allotment it is difficult to pinpoint any specific factors affecting micronutrient uptake by plants in the three areas. 

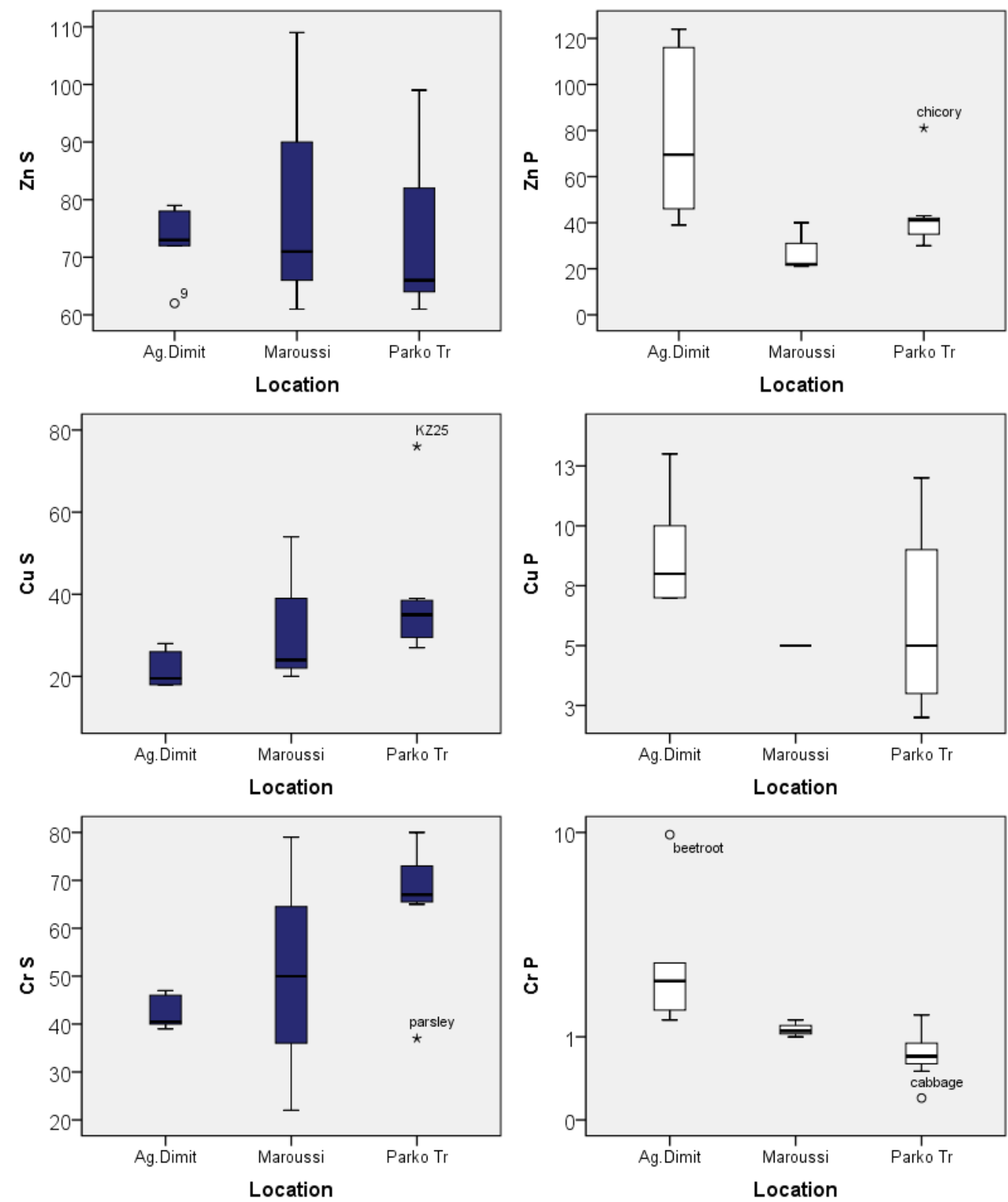

Figure 3 - Boxplot comparisons of soil (S- dark boxes) and plant (P- white boxes) concentrations of selected elements between the three communal allotment study areas (Agios Dimitrios $(n=8)$, Maroussi $(n=6)$ and Tritsis Park $n=7)$ ). Concentrations are expressed as $\mathrm{mg} / \mathrm{kg}$ except for $\mathrm{Cr}$ in plants which is in $\mu \mathrm{g} / \mathrm{kg}$. 

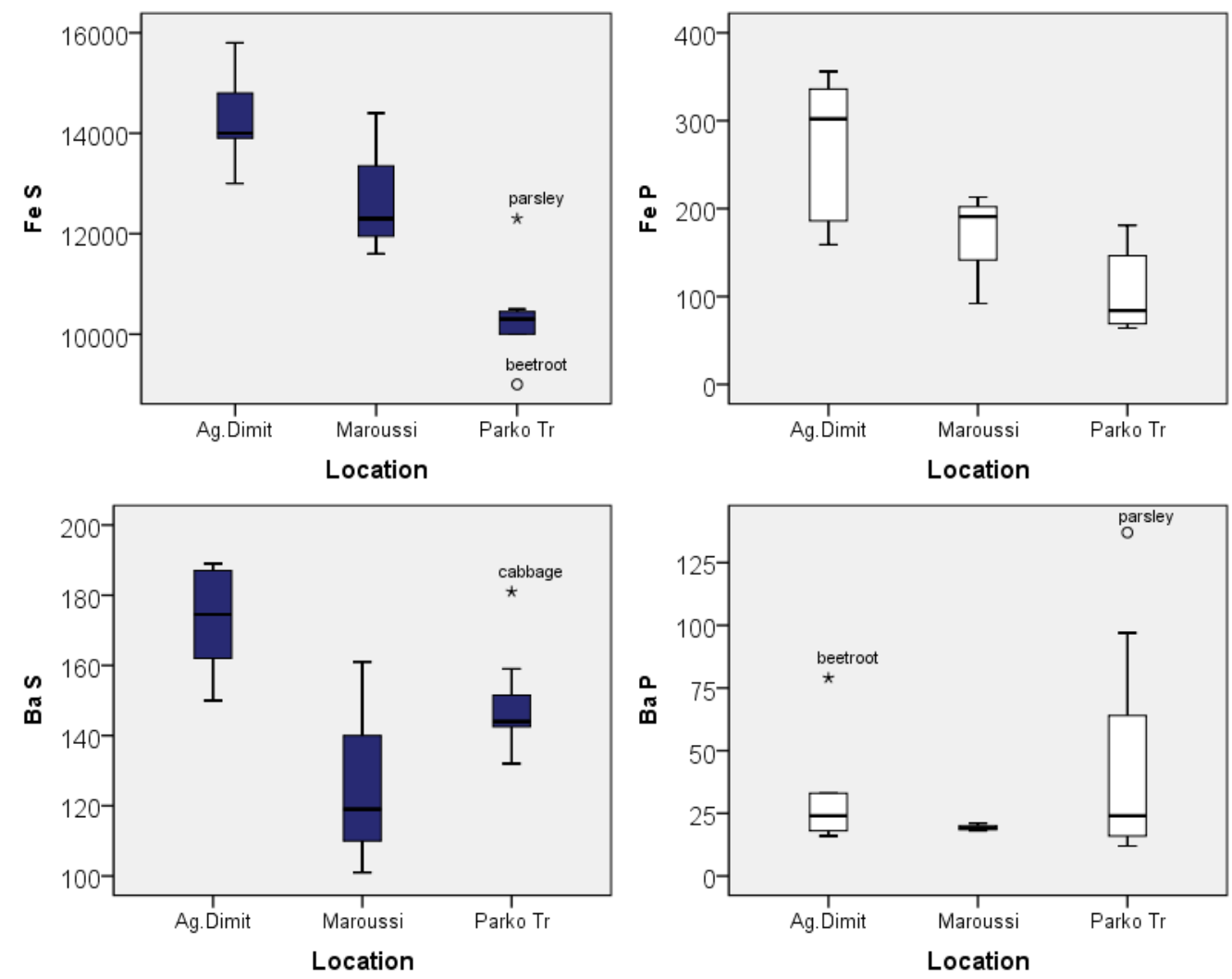

Figure 3 - continue

\section{Conclusions}

Data on concentrations of heavy metals in soil and plants from urban agriculture areas in the city of Athens are presented for the first time. The geochemical signature of soil in three communal allotments and three private house gardens was studied with respect to $\mathrm{Fe}, \mathrm{Mn}, \mathrm{Ba}, \mathrm{Zn}, \mathrm{Ni}, \mathrm{Cr}, \mathrm{Co}$, $\mathrm{Pb}, \mathrm{Cu}$ and $\mathrm{Cd}$ and concentration levels in the edible parts of produced vegetables were measured. Although no systematic pattern was observed, concentration levels in soil were in general lower than the median values previously reported for Athens soils (Kelepertzis and Argyraki, 2015). Heavy metal concentrations in plant tissues were below detection limit for $\mathrm{Pb}$ and $\mathrm{Cd}$ and within normal ranges for healthy plant growth regarding the rest of the studied elements. No significant correlation was observed between pseudototal or acetic acid extractable concentrations in soil and plants, supporting that a more complex mechanism controls micronutrient uptake by plants. Vegetable produce from the communal allotment of Agios Dimitrios contains higher concentrations of $\mathrm{Zn}, \mathrm{Cu}$, $\mathrm{Cr}$ and $\mathrm{Fe}$ compared to the other two communal agriculture areas. Further interdisciplinary research is needed in order to determine the controlling factors of micronutrient uptake within the urban environment.

\section{Acknowledgments}

The authors would like to thank Dr. Ioannis Mitsis of the Laboratory of Economic Geology and Geochemistry, University of Athens for his invaluable help and guidance during the plant tissue digestions. Also Dr. Efstratios Kelepertzis for his help during sample preparation and analytical procedures. Special thanks are given to Dr. Adil Bakir for his involvement in chemical determinations of geochemical solutions at the analytical facilities of School of Earth \& 
Environmental Sciences, University of Portsmouth, UK. Ms. Asimakopoulou of the Municipality of Agios Dimitrios, Ms. Koroni of the Municipality of Maroussi, Mr. Dritsoulas of the NGO "The Center of the Earth" as well as the owners of the private gardens are greatly acknowledged for their help during field sampling.

\section{References}

Argyraki, A. and Kelepertzis, E., 2014. Urban soil in Athens, Greece: The importance of local geology in controlling the distribution of potentially harmful trace elements, Science of The Total Environment, 482-483, 366-377.

Bouyoucos, G.J., 1962. Hydrometer method improved for making particle size analysis of soils, Agronomy Journal, 54, 464-465.

ISO 10390, 1994. Soil quality- determination of $\mathrm{pH}$.

Jaworowski, C., 1981. The effect of copper and fertilization with various forms of nitrogen on some physiological indices in maize, Acta Agra, Silvistria, 20, 95 (Po).

Kabata-Pendias, A. and Pendias, H., 1979. Trace elements in the Biological environment, Wyd. Geol., Warsaw, 300 (Po).

Kabata-Pendias, A. and Pendias, H., 1992. Trace Elements in Soils and Plants, CRS Press, Boca Raton, FI.

Kabata-Pendias, A. and Pendias, H., 2001. Trace Elements in Soils and Plants (third edition), CRS Press, Boca Raton, FI.

Kelepertzis, E. and Argyraki, A., 2015. Geochemical associations for evaluating the availability of potentially harmful elements in urban soils: Lessons learnt from Athens, Greece, Applied Geochemistry, 59, 63-73.

Manta, D.S., Angelone, M., Bellanca, A., Neri, R. and Sprovieri, M., 2002. Heavy metals in urban soils: a case study from the city of Palermo (Silicy), Italy, Science Total Environ., 300, 229-43.

Rodrigues, S., Urquhart, G., Hossack, I., Pereira, M.A., Duarte, A.C., Davidson, C., Hurtshouse, A., Tucker, P. and Roberston, D., 2009. The influence of anthropogenetic and natural geochemical factors of urban soil quality variability: a comparison between Glasgow, UK and Aveiro, Portugal, Environ. Chem. Let., 7, 141-8.

Tahmasbian, I., Nasrazadani, A., Shoja, H. and Safari Sinegani, A.A., 2013. The effects of human activities and different land use on trace elements pollution in urban topsoil of Isfahan (Iran), Environ Earth Sci.

US-EPA, 2002. Methods for the determination of total organic carbon (TOC) in soils and sediments. Report No. NCEA-C-1282, EMASC-001, Las Vegas.

Warren, H.V., Delavault, R.E., Fletcher, K. and Wilks, E., 1970. Variation in the copper, zinc, lead and molybdenum content of some British Columbia vegetables, In: Trace Subst. environ. Health, Vol.4, Hemphill, D.D., ed., University of Missouri Columbia, MO, 94. 